\title{
OPTIMIZATION OF MACHINING PARAMETERS IN TURNING OPERATION USING COMBINED TOPSIS AND AHP METHOD
}

\author{
Balasubramaniyan Singaravel, Thangiah Selvaraj
}

Original scientific paper

Multi objective optimization is an important issue in complex industrial problems. In this experimental study, optimum machining parameters are determined in turning operation of EN25 steel with coated carbide tools using combined Technique for Order Preference by Similarity to Ideal Solution (TOPSIS) and Analytic Hierarchy Process (AHP) method. This technique is a multi-objective optimization method which has been adopted to simultaneously minimize micro hardness, surface roughness and maximize material removal rate (MRR). The result indicates the effectiveness of this approach. This method is applicable to all machining operations with greater number of objectives simultaneously.

Keywords: AHP; EN25 steel; optimization; TOPSIS; turning

Optimizacija parametara obrade u postupcima tokarenja primjenom kombinacije TOPSIS i AHP metode

Izvorni znanstveni članak Optimizacija s više ciljeva važno je pitanje u složenim industrijskim problemima. U ovom eksperimentalnom istraživanju, optimalni parametri obrade određivani su pri tokarenju EN25 čelika s alatima od tvrdog metalnog karbida primjenom kombinacije metode TOPSIS (Technique for Order Preference by Similarity to Ideal Solution) i AHP (Analytic Hierarchy Process). To je metoda optimizacije s više ciljeva, primijenjena kako bi se istovremeno do minimuma smanjila mikro tvrdoća, površinska tvrdoća, a do maksimuma povećao učinak odvajanja čestica (MRR). Rezultat pokazuje učinkovitost tog pristupa. Ova se metoda može primijeniti u svim postupcima obrade s istovremeno većim brojem ciljeva.

Ključne riječi: AHP; EN25 čelik; optimizacija; tokarenje; TOPSIS

\section{Introduction}

Generally the machining parameters are chosen based on the knowledge, operators experience and also referring to standard handbooks. The selected machining parameters may not be the optimal solution which leads to higher cost of the product [1]. High machining performance is obtained by the selection of optimum machining parameters [2]. Optimization techniques help as to select the optimum combination of machining parameters [3].

In the area of manufacturing new materials are developed to meet industrial requirements, but it is not possible to utilize them directly. Hence experimental study is required [4]. EN25 steel gives better mechanical property and atmospheric corrosion resistance than conventional carbon steel [5]. Microstructure and hardness of the EN25 steel was analyzed to estimate the effect of process parameters in laser hardening process [6]. EN25 steel is nickel chromium molybdenum high strength low alloy medium carbon steel which is used in various industries like automobile and aircraft industries [7].

Machining induced surface integrity can be characterized by various factors in which surface roughness and micro hardness are important factors [8]. The degree of work hardening can be calculated by surface micro hardness [9]. Micro hardness is one of the significant parameters in the surface integrity study [10]. The evaluation of surface integrity is achieved by surface roughness and micro hardness measurements [11]. Surface roughness of the machined components influences the fatigue strength, wear resistance and corrosion resistance [12]. For increased productivity of machined component MRR plays a vital role. Hence selection of optimum combination of machining parameter is highly desirable in turning operation [13].

Multi criteria decision making (MCDM) method is the multi objective optimization technique that has been used to evaluate the alternatives. The objectives with the highest relative closeness to the positive solution are suggested for optimal combination of input parameters. TOPSIS is a multi-criteria decision making method developed by Yoon and Wang, which involves determination of the shortest distance to the positive solution and greatest distance from the negative solution. The Electric Discharge Machining parameters were optimized by TOPSIS Method. TOPSIS has been broadly accepted by the manufacturing domain for multi criteria selection [14]. In composite product development, optimal sub system selection was evaluated with the help of TOPSIS method [15]. Optimal input parameters were determined by using combined TOPSIS and AHP method in the machining of Inconel 718 [16]. The machinabilty has been evaluated in turning operation of titanium using combined TOPSIS and AHP method [17]. Best lubricant is selected among a given number of lubricants using combined TOPSIS and AHP method in turning of EN31steel [18]. An overall performance was obtained for its operational activities in the success of a manufacturing company using TOPSIS and AHP method [19]. Even though TOPSIS is more reliable while dealing with the tangiable attributes and in the assessment of number of alternatives, it needs an appropriate procedure to determine the weight criteria of each objective. AHP method has been used to assign the weight of each criterion. AHP provides an effective structured technique based on mathematical concept [20]. In this work AHP is applied to find the weight of each criterion. Hence advantages of TOPSIS and AHP methods are combined to find the turning performance. 
The aim of this study is to find the optimal combination of machining parameters in turning of EN25 steel with Physical Vapour Deposition (PVD) and Chemical Vapour Deposition (CVD) coated carbide tools using combined TOPSIS and AHP method for simultaneous minimization of micro hardness, surface roughness and maximization of metal removal rate.

\section{Experimental setup}

The work piece used in this study is EN25 steel and the chemical composition of this material is shown in Tab. 1. This material possesses higher mechanical strength and corrosion resistance than carbon steel hence it is widely used in heavy duty drive shaft and gear shaft.The CNMG120404 coated carbide inserts are used as the cutting tool materials. The turning operations are conducted on CNC turning center using coated carbide insert for the machining of BS-970-1955-EN 25 steel (DIN standard of 32NiCrMo10-4).

Table 1 Chemical composition (wt \%) of EN 25 steel \begin{tabular}{|l|l|l|l|l|l|l|l|l|l|}
\hline Material & $\mathrm{C}$ & $\mathrm{Si}$ & $\mathrm{Mn}$ & $\mathrm{Ni}$ & $\mathrm{Cr}$ & $\mathrm{Mo}$ & $\mathrm{S}$ & $\mathrm{P}$ & $\mathrm{Fe}$ \\
\hline
\end{tabular} \begin{tabular}{|l|l|l|l|l|l|l|l|l|l|}
\hline EN 25 & 0,293 & 0,185 & 0,629 & 2,49 & 0,577 & 0,51 & 0,02 & 0,02 & Balance \\
\hline
\end{tabular}

\begin{tabular}{|c|c|c|c|}
\hline \multicolumn{3}{|c|}{ Table 2 Machining parameter levels } \\
\cline { 2 - 4 } Factors & Level 1 & Levels & Level 3 \\
\hline $\begin{array}{c}\text { Types of coated } \\
\text { tool }\end{array}$ & CVD coated tool & $\begin{array}{c}\text { PVD coated } \\
\text { tool }\end{array}$ & --- \\
\hline $\begin{array}{c}\text { Cutting speed } \\
\text { (m/min) }\end{array}$ & 113 & 179 & 245 \\
\hline $\begin{array}{c}\text { Feed rate } \\
(\mathrm{mm} / \text { rev })\end{array}$ & 0,10 & 0,18 & 0,26 \\
\hline $\begin{array}{c}\text { Depth of cut } \\
(\mathrm{mm})\end{array}$ & 0,6 & 1,2 & 1,8 \\
\hline
\end{tabular}

Table 3 Experimental layout and their results

\begin{tabular}{|c|c|c|c|c|c|c|c|}
\hline $\begin{array}{l}\stackrel{0}{Z} \\
\dot{\pi}\end{array}$ & 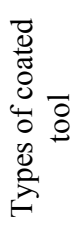 & 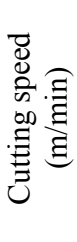 & 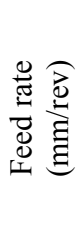 & 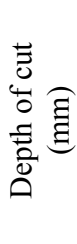 & 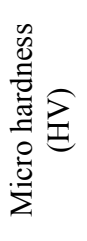 & 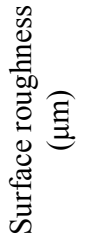 & 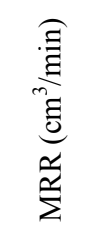 \\
\hline 1 & CVD & 113 & 0,10 & 0,6 & 368 & 1,01 & 6,78 \\
\hline 2 & CVD & 113 & 0,18 & 1,2 & 371 & 1,28 & 24,408 \\
\hline 3 & CVD & 113 & 0,26 & 1,8 & 374 & 1,51 & 52,884 \\
\hline 4 & CVD & 179 & 0,10 & 0,6 & 378 & 1,45 & 10,74 \\
\hline 5 & CVD & 179 & 0,18 & 1,2 & 382 & 1,67 & 38,664 \\
\hline 6 & CVD & 179 & 0,26 & 1,8 & 384 & 1,89 & 83,772 \\
\hline 7 & CVD & 245 & 0,10 & 1,2 & 394 & 1,82 & 29,4 \\
\hline 8 & CVD & 245 & 0,18 & 1,8 & 396 & 2,04 & 79,38 \\
\hline 9 & CVD & 245 & 0,26 & 0,6 & 391 & 2,11 & 38,22 \\
\hline 10 & PVD & 113 & 0,10 & 1,8 & 399 & 1,78 & 20,34 \\
\hline 11 & PVD & 113 & 0,18 & 0,6 & 389 & 2,07 & 12,204 \\
\hline 12 & PVD & 113 & 0,26 & 1,2 & 393 & 2,19 & 35,256 \\
\hline 13 & PVD & 179 & 0,10 & 1,2 & 412 & 2,13 & 21,48 \\
\hline 14 & PVD & 179 & 0,18 & 1,8 & 414 & 2,28 & 57,996 \\
\hline 15 & PVD & 179 & 0,26 & 0,6 & 408 & 2,39 & 27,924 \\
\hline 16 & PVD & 245 & 0,10 & 1,8 & 434 & 2,32 & 44,1 \\
\hline 17 & PVD & 245 & 0,18 & 0,6 & 429 & 2,47 & 26,46 \\
\hline 18 & PVD & 245 & $0 ., 26$ & 1,2 & 431 & 2,62 & 76,44 \\
\hline
\end{tabular}

In this study, the identified machining parameters and their range of values are mentioned in Tab. 2. Total of 18 experiments are conducted and their performance characteristics are determined as shown in Tab. 3. The turning operations are conducted up to a length of $70 \mathrm{~mm}$ under wet condition.

In the measurement of micro hardness of the machined surface Vickers micro hardness tester is used. Machined samples are cut and then mounted using abrasive cutter and hot mounting machine. The mounted specimen is subjected to a sequence of polishing using 180 to $1000 \mathrm{SiC}$ grit metallurgical papers. The sequence of polishing consists of using 180, 240, 320, 400, 600, 800 and 1000 grit $\mathrm{SiC}$ papers. Further the hand polished specimens are polished on cloth polishing machine with the help of fine alumina powder to achieve mirror like surface. Micro hardness is calculated at three locations and average value is considered for further analysis.

The measurement of roughness on the machined surface is an important criterion in industrial applications. It is defined as the arithmetic average of the absolute value of the heights of roughness irregularities from the mean value measured within a sampling length. Mitutoyo surftest SJ 301 roughness tester is used to find the arithmetic surface roughness for each sample.

Productivity of any machining operation mainly depends on its rate of material removal. The rate of material removal for a turning operation is given by the product of cutting speed, feed rate, and depth of cut. MRR in turning operation is defined as the volume of the material that is removed per unit time in $\mathrm{cm}^{3} / \mathrm{min}$.

$M R R=v \cdot f \cdot a$,

where $M R R$ is the volume of material removal rate $\left(\mathrm{cm}^{3} / \mathrm{min}\right), v$ is the cutting speed $(\mathrm{m} / \mathrm{min}), f$ is the feed rate $(\mathrm{mm} / \mathrm{rev})$, and $a$ is the depth of cut $(\mathrm{mm})$.

\section{Methodology}

The Multi criteria decision making methods (MCDM) are widely accepted in manufacturing domain for the selection of optimal solution from a finite number of alternatives. MCDM techniques are powerful and an effective tool particularly in the last decade. TOPSIS is one of the MCDM methods for solving multiple criteria. The concept of this method is choosing the best alternatives having shortest distance from the positive solution and the farthest from the negative solution. These hypothetical solutions correspond to the maximum and minimum attribute values in the database that comprise satisfy solutions. The closest hypothetical best and farthest hypothetical worst is used to obtain the best solutions [21].The tangible attributes and the number of alternatives are efficiently analyzed by TOPSIS, but it is required to find the weight criteria of each objective [17]. AHP method is used to determine the weight criteria of various attributes in accordance with the objectives. AHP was introduced by Thomas L. Satty in 1980. In AHP method the pertinent data for weight criteria of each objective are obtained by using a set of pair wise comparisons [22, 23]. Hence, the advantages of both 
methods are taken and presented as a combined TOPSIS and AHP method.

The following procedures are used to select the best alternatives in combined TOPSIS and AHP method [17].

Step 1: The objective and the important evaluation attributes are determined. For this particular problem MRR is considered as a beneficial attribute and (i.e.) maximization, while micro hardness and surface roughness are considered as non beneficial attributes (i.e.) minimization.

Step 2: All the information available is represented in the form of a decision matrix.

$\boldsymbol{D}_{18 \times 3}=\left[\begin{array}{ccc}368 & 1,01 & 6,780 \\ 271 & 1,28 & 24,408 \\ 374 & 1,51 & 52,884 \\ 378 & 1,45 & 10,740 \\ 382 & 1,67 & 38,664 \\ 384 & 1,89 & 83,772 \\ 394 & 1,82 & 29,400 \\ 396 & 2,04 & 79,380 \\ 391 & 2,11 & 38,220 \\ 399 & 1,78 & 20,340 \\ 389 & 2,07 & 12,204 \\ 393 & 2,19 & 35,256 \\ 412 & 2,13 & 21,480 \\ 414 & 2,28 & 57,996 \\ 408 & 2,39 & 27,924 \\ 434 & 2,32 & 44,100 \\ 429 & 2,47 & 26,460 \\ 431 & 2,62 & 76,440\end{array}\right]$.

Eq. (2) shows the decision matrix $\boldsymbol{D}_{18 \times 3}$.

Step 3: The normalized matrix $\boldsymbol{N}_{i j}$ is determined by using the following formula

$$
\boldsymbol{N}_{i j}=\frac{x_{i j}}{\sqrt{\sum x_{i j}^{2}}} .
$$

The normalized decision matrix, $\boldsymbol{N}_{18 \times 3}$, is calculated using Eq. (3) given as

$$
\boldsymbol{N}_{18 \times 3}=\left[\begin{array}{ccc}
0,2182 & 0,1196 & 0,0359 \\
0,2200 & 0,1515 & 0,1294 \\
0,2217 & 0,1787 & 0,2803 \\
0,2241 & 0,1716 & 0,0569 \\
0,2265 & 0,1977 & 0,2049 \\
0,2277 & 0,2237 & 0,4440 \\
0,2336 & 0,2154 & 0,1558 \\
0,2348 & 0,2415 & 0,4208 \\
0,2318 & 0,2498 & 0,2026 \\
0,2366 & 0,2107 & 0,1078 \\
0,2306 & 0,2450 & 0,0647 \\
0,2330 & 0,2592 & 0,1869 \\
0,2443 & 0,2521 & 0,1139 \\
0,2455 & 0,2699 & 0,3074 \\
0,2419 & 0,2829 & 0,1480 \\
0,2573 & 0,2746 & 0,2338 \\
0,2543 & 0,2924 & 0,1403 \\
0,2555 & 0,3101 & 0,4052
\end{array}\right] .
$$

Eq. (4) shows the Normalized decision matrix $\boldsymbol{N}_{18 \times 3}$.

Step 4: The weighted normalized decision matrix is constructed by multiplying the normalized decision matrix by its associated weights.

$\boldsymbol{W}_{i j}=\boldsymbol{N}_{i j} \times W_{j}$,

where $\boldsymbol{N}_{i j}$ is the normalized matrix and $W_{j}$ is the weight criteria.

The weight $\left(W_{j}\right)$ of each criteria is calculated by AHP method and the detailed procedure is given below [17].

1) Determine the relative importance of different attributes with respect to the objective. To do so one must construct a pair-wise comparison matrix. Assuming $N$ attributes, the pair-wise comparison of attribute $i$ with attribute $j$ yields a square matrix $\boldsymbol{A}_{N \times N}$, where $a_{i j}$ denotes the comparative importance of attribute $i$ with respect to attribute $j$. In the matrix, $a_{i j}=1$ when $i=j$ and $a_{i j}=1 / a_{i j}$. This can be described as follows:

$$
\boldsymbol{A}_{N \times N}=\left[\begin{array}{cccccc}
a_{11} & a_{12} & a_{13} & - & - & a_{1 N} \\
a_{21} & a_{22} & a_{23} & - & - & a_{2 N} \\
a_{31} & a_{32} & a_{33} & - & - & a_{3 N} \\
- & - & - & - & - & - \\
- & - & - & - & - & - \\
a_{N 1} & a_{N 2} & a_{N 3} & - & - & a_{N N}
\end{array}\right] .
$$

Pair wise comparison matrix

$$
\boldsymbol{A}_{N \times N}=\left[\begin{array}{ccc}
1 & 3 & 1 \\
\frac{1}{3} & 1 & 1 \\
1 & 1 & 1
\end{array}\right] \text {. }
$$

The relative normalized weight $\left(W_{j}\right)$ of each attribute is calculated by determining the geometric mean of the $i^{\text {th }}$ row as given in Eq. (7) and normalizing the geometric means of rows in the comparison matrix as given in Eq. (8) by

$$
\begin{gathered}
G M_{i}=\frac{\left[\prod_{J=1}^{N} a i j\right]}{N}, \\
W_{j}=\frac{G M_{i}}{\sum_{i=1}^{N} G M_{i}},
\end{gathered}
$$

2) Determine matrix $\boldsymbol{A}_{3}$ and $\boldsymbol{A}_{4}$ such that $\boldsymbol{A}_{3}=\boldsymbol{A}_{1} \times \boldsymbol{A}_{2}$ and $\boldsymbol{A}_{4}=\boldsymbol{A}_{3} / \boldsymbol{A}_{2}$, where $A_{2}=\left[W_{1}, W_{2}, \ldots, W_{N}\right]^{\mathrm{T}}$.

3) Calculate the maximum Eigen value $\left(\lambda_{\max }\right)$, which is the average of matrix $\boldsymbol{A}_{4}$.

4) Determine the consistency index $C I=\frac{\lambda_{\max }-N}{N-1}$.

The smaller value of $C I$ the smaller is the deviation from the consistency.

5) Evaluate the random index $(R I)$ for the number of attributes used in decision-making.

6) Determine the consistency ratio $(C R=C I / R I)$. 
Usually, a $C R$ of 0,1 or less is considered to be acceptable, and it reflects an informed judgment which could be attributed to the analyst's knowledge of the problem.

The relative importance matrix has been derived based on the process planner and machining process requirements given in Eq. (6). The objectives are surface roughness, micro hardness and $M R R$. In these, attributes micro hardness and surface roughness are non-beneficial (minimum values) and other $M R R$ is beneficial (maximum values). The normalized weights of each attribute is; $W_{\text {microhardness }}=0,46 ; W_{\text {surface roughness }}=0,221$ and $W_{\text {MRR }}=0,319$. The value of $\lambda_{\max }$ is 3,1356 and Consistency Ratio $(C R)=0,0678$, which is much less than the allowed $C R$ value of 0,1 .Thus, there is good consistency in the judgment of relative importance matrix.

The weighted normalized value $\boldsymbol{W}_{18 \times 3}$ is calculated using (5) is given as

$$
\boldsymbol{W}_{18 \times 3}=\left[\begin{array}{ccc}
0,1004 & 0,0264 & 0,0115 \\
0,1012 & 0,0335 & 0,0413 \\
0,1020 & 0,0395 & 0,0894 \\
0,1031 & 0,0379 & 0,0182 \\
0,1042 & 0,0437 & 0,0654 \\
0,1047 & 0,0494 & 0,1417 \\
0,1075 & 0,0476 & 0,0497 \\
0,1080 & 0,0534 & 0,1342 \\
0,1066 & 0,0552 & 0,0646 \\
0,1088 & 0,0466 & 0,0344 \\
0,1061 & 0,0541 & 0,0206 \\
0,1072 & 0,0573 & 0,0596 \\
0,1124 & 0,0557 & 0,0363 \\
0,1129 & 0,0596 & 0,0981 \\
0,1113 & 0,0625 & 0,0472 \\
0,1184 & 0,0607 & 0,0746 \\
0,1170 & 0,0646 & 0,0447 \\
0,1175 & 0,0685 & 0,1293
\end{array}\right] .
$$

Eq. (9) shows the Weighted normalized matrix $\boldsymbol{W}_{18 \times 3}$.

Step 5: Determination of the positive ideal solution $\left(A^{* *}\right)$ and the negative ideal solution $\left(A^{*}\right)$. These are calculated by using Eq. (10) and Eq. (11):

$$
\begin{aligned}
& A^{* *}=\left\{\left(\max W_{i j} \mid j \in J\right),\left(\min W_{i j} \mid j \in J^{\prime}\right)\right\}, \\
& A^{*}=\left\{\left(\min W_{i j} \mid j \in J\right),\left(\max W_{i j} \mid j \in J^{\prime}\right)\right\},
\end{aligned}
$$

$J=1,2,3, \ldots, n-$ where $J$ is associated with the benefit criteria $J^{\prime}=1,2,3, \ldots, n-$ where $J^{\prime}$ is associated with the cost criteria.

$$
\begin{aligned}
& A_{\text {microhardness }}^{* *}=0,1004 \\
& A_{\text {microhardness }}^{*}=0,1184 \\
& A_{\text {surface roughness }}^{* *}=0,0264 \\
& A_{\text {surface roughness }}^{*}=0,0685 \\
& A_{M R R}^{* *}=0,1417 \\
& A_{M R R}^{*}=0,0115
\end{aligned}
$$

Step 6: The separation measure is calculated.
The separation of each alternative from the positive ideal one is given by

$$
S_{i}^{* *}=\sqrt{\sum\left(\boldsymbol{W}_{i j}-A_{j}^{* *}\right)^{2}}, j=1, \text { where } i=1,2, \ldots, m \text {. }
$$

Similarly, the separation of each alternative from the negative ideal one is given by:

$S_{i}^{*}=\sqrt{\sum\left(\boldsymbol{W}_{i j}-A_{j}^{*}\right)^{2}}, j=1$, where $i=1,2, \ldots, m$.

Step 7:The relative closeness is calculated to the ideal solution.

$C_{i}^{*}=\frac{S_{i}^{*}}{S_{i}^{* *}+S_{i}^{*}}$.

The larger the $C_{i}^{*}$ value the better is the performance of the alternatives.

The separation measure of positive, negative ideal solution and relative closeness value are mentioned in Tab. 4.

Step 8: Rank the relative closeness value.

Table 4 Separation measure of positive, negative ideal solutions and relative closeness value

\begin{tabular}{|c|c|c|c|c|}
\hline S1. No & $\begin{array}{c}\text { Separation } \\
\text { measure of } \\
\text { positive ideal } \\
\text { solution }\left(S^{* *}\right)\end{array}$ & $\begin{array}{c}\text { Separation } \\
\text { measure of } \\
\text { negative ideal } \\
\text { solution }\left(S^{*}\right)\end{array}$ & $\begin{array}{c}\text { Relative } \\
\text { closeness } \\
\left(C^{*}\right)\end{array}$ & Rank \\
\hline 1 & 0,01696 & 0,00210 & 0,11037 & 13 \\
\hline 2 & 0,01014 & 0,00241 & 0,19247 & 10 \\
\hline 3 & 0,00291 & 0,00718 & 0,71208 & 4 \\
\hline 4 & 0,01540 & 0,00121 & 0,07336 & 16 \\
\hline 5 & 0,00614 & 0,00372 & 0,37775 & 7 \\
\hline 6 & 0,00055 & 0,01749 & 0,96963 & 1 \\
\hline 7 & 0,00896 & 0,00202 & 0,18402 & 11 \\
\hline 8 & 0,00084 & 0,01540 & 0,94835 & 2 \\
\hline 9 & 0,00681 & 0,00314 & 0,31572 & 8 \\
\hline 10 & 0,01199 & 0,00110 & 0,08413 & 15 \\
\hline 11 & 0,01546 & 0,00044 & 0,02791 & 18 \\
\hline 12 & 0,00774 & 0,00256 & 0,24928 & 9 \\
\hline 13 & 0,01211 & 0,00081 & 0,06332 & 17 \\
\hline 14 & 0,00316 & 0,00760 & 0,70623 & 5 \\
\hline 15 & 0,01035 & 0,00136 & 0,11642 & 12 \\
\hline 16 & 0,00600 & 0,00404 & 0,40230 & 6 \\
\hline 17 & 0,01113 & 0,00112 & 0,09161 & 14 \\
\hline 18 & 0,00222 & 0,01386 & 0,86192 & 3 \\
\hline & & & & \\
\hline
\end{tabular}

\section{Results and discussion}

The objective of the present work is to optimize the machining parameters in turning operation using combined TOPSIS and AHP method for optimizing the multi-objectives. The most important measure in the combined TOPSIS and AHP method for analyzing experimental data is relative closeness. In this study, the relative closeness should have a maximum value to obtain optimum cutting conditions, according to the TOPSIS method. Two categories of performance characteristics, i.e., minimization and maximization are selected in this study. To obtain optimal machining performance, the minimization characteristic for micro hardness, surface 
roughness and maximization characteristics for $M R R$ have been taken. The results obtained from the experimental runs are shown in Tab. 3. Tab. 4 shows data of relative closeness for micro hardness, surface roughness and $M R R$.

The relative closeness is used to determine the optimum combination of machining parameters for minimizing micro hardness, surface roughness and maximizing MRR. The maximum relative closeness indicates the minimum values of micro hardness, surface roughness and maximum values of MRR and their values are cutting speed of $179 \mathrm{~m} / \mathrm{min}$, feed rate of $0,26 \mathrm{~mm} / \mathrm{rev}$ and depth of cut of $1,8 \mathrm{~mm}$ with CVD coated carbide tool. This method is simple with less computational steps when compared to other methods such as Artificial Neural Network, Genetic Algorithm and grey relational analysis.

\section{Conclusions}

In the present study combined TOPSIS and AHP method, a multi objective optimization method, have been adopted to find the optimum combination of machining parameters such as cutting speed, feed rate and depth of cut for simultaneous minimization of micro hardness, surface roughness and maximization of MRR while turning EN25 steel with coated carbide tools.

- Analytic Hierarchy Process is successfully employed to find the weight factors involved for all responses.

- The combined TOPSIS and AHP method is used to select the best combination of machining parameters in turning operation. The alternatives are sorted in a ranking wise set with their relative closeness as 1310-4-16-7-1-11-2-8-15-18-9-17-5-12-6-14-3.

- From the relative closeness values, it is evident that the machining parameter assigned as alternative 6 is the first choice, alternative 8 is the second choice and 11 is the last choice for the given application under given set of conditions.

- The optimal combination of turning process parameter for simultaneous minimization of micro hardness, surface roughness and maximization of MRR are cutting speed $179 \mathrm{~m} / \mathrm{min}$, feed rate 0,26 $\mathrm{mm} / \mathrm{rev}$ and depth of cut $1,8 \mathrm{~mm}$ with CVD coated carbide tool.

- The combined TOPSIS and AHP method consider weight criteria of each objective for a better and accurate evaluation of the alternatives.

- This method has the advantage of utilizing simple computational steps for simultaneous optimization of multiple objectives.

\section{References}

[1] Thakur, D.; Ramamoorthy, B.; Vijayaraghavan, L. Optimization of high speed turning parameters of superalloy Inconel 718 material using Taguchi technique. // Indian Journal of Engineering \& Materials Sciences. 16, 1(2009), pp. 44-50.

[2] Yang, W. H.; Tarng, Y. S. Design optimization of cutting parameters for turning operations based on the Taguchi method. // Journal of Materials Processing Technology. 84, 1-3(1998), pp. 122-129. DOI: 10.1016/s0924-0136(98)00079-x

[3] Zuperl, U.; Cus, F.; Milfelner, M. Fuzzy control strategy for an adaptive force control in end-milling. // Journal of
Materials Processing Technology. 164-165, 15(2005), pp. 1472-1478. DOI: 10.1016/j.jmatprotec.2005.02.143

[4] Kadirgama, K.; Noor, M. M.; Rahman, M. M. Optimization of Surface Roughness in End Milling Using Potential Support Vector Machine. // Arabian Journal of Science and Engineering. $\quad 37, \quad 8(2012)$, pp. 2269-2275. DOI: 10.1007/s13369-012-0314-2

[5] Babu, P.; Buvanashekaran, G.; Balasubramanian, K. R. Experimental studies on the microstructure and hardness of laser transformation hardening of low alloy steel. // Transactions of the Canadian Society for Mechanical Engineering. 36, 3(2012), pp. 241-258.

[6] Babu, P. D.; Buvanashekaran, G.; Balasubramanian, K. R. Experimental investigation of laser transformation hardening of low alloy steel using response surface methodology. // The International Journal of Advanced Manufacturing Technology. 67, 5-8(2013), pp.1883-1897.

[7] Babu, P. D.; Buvanashekaran, G.; Balasubramanian, K. R. Dry sliding wears of laser hardened low alloy steel at room and elevated temperatures. // Proceedings of the institution of mechanical engineers, Part $\mathrm{J}$; Journal of engineering tribology. 227, 10(2013), pp.1138-1149. DOI: 10.1177/1350650113481530

[8] Schwach, D. W.; Guo, Y. B. A fundamental study on the impact of surface integrity by hard turning on rolling contact fatigue. // International Journal of Fatigue. 28, 12(2006), pp. 1838-1844. DOI: 10.1016/j.ijfatigue.2005.12.002

[9] Thakur, D. G.; Ramamoorthy, B.; Vijayaraghavan, L. Effect of cutting parameters on the degree of work hardening and tool life during high-speed machining of Inconel 718. // The International Journal of Advanced Manufacturing Technology. 59, 5-8(2012), pp. 483-489. DOI: 10.1007/s00170-011-3529-6

[10] Krolczyk, G.; Nicslony, P.; Legutko, S. Micro hardness and Surface Integrity in Turning Process of Duplex Stainless Steel (DSS) for Different Cutting Conditions. // Journal of Materials Engineering and Performance. 23, 3(2014), pp. 859-866. DOI: $10.1007 / \mathrm{s} 11665-013-0832-4$

[11] Jasinevicius, R. G.; De Campos, G. P.; Montanari, L.; Tsukamoto, R.; Garcia, J. P.; Camargo, R.; Duduch, J. G.; Porto, A. J. V. Influence of the Mechanical and Metallurgical State of an Al-Mg Alloy on the Surface Integrity in Ultra precision Machining. // Journal of the Brazilian Society of Mechanical Sciences and Engineering. 25, 3(2003), pp. 222-228. DOI: 10.1590/S167858782003000300002

[12] Singh, D.; Rao, P.V. A surface roughness prediction model for hard turning process. // The International Journal of Advanced Manufacturing Technology. 32, 11-12(2007), pp. $1115-1124$

[13] Gaitonde, V. N.; Karnik, S. R.; Paulo Davim, J. Multiperformance Optimization in Turning of FreeMachining Steel Using Taguchi Method and Utility Concept. // Journal of Materials Engineering and Performance. 18, 3(2009), pp. 231-236. DOI: 10.1007/s11665-008-9269-6

[14] Gadakh, V. S. Parametric optimization of wire electrical discharge machining using TOPSIS method. // Advances in Production Engineering \& Management.7, 3(2012), pp.157164. DOI: 10.14743/apem2012.3.138

[15] Prabhakaran, R. D.; Babu, B. J. C.; Agrawal, V. P. Optimum Selection of a Composite Product System Using MADM Approach. // Materials and Manufacturing Processes. 21, 8(2006), pp. 883-891. DOl: 10.1080/10426910600773472

[16] Thirumalai, R.; Senthilkumaar, J. S. Multi-criteria decision making in the selection of machining parameters for Inconel 718. // Journal of Mechanical Science and Technology. 27, 4(2013), pp. 1109-1116. DOI: $10.1007 / \mathrm{s} 12206-013-0215-7$ 
[17] Rao, R. V. Machinability evaluation of work materials using a combined multiple attribute decision-making method. // The International Journal of Advanced Manufacturing Technology. 28, 3-4(2006), pp. 221-227.

[18] Abhang, L. B.; Hameedullah, M. Selection of lubricant using combined multiple attribute decision making method. // Advances in Production Engineering and management. 7, 1 (2012), pp. 39-50. DOI: 10.14743/apem2012.1.129

[19] Yurdakul, M.; Ic, Y. T. Development of a performance measurement model for manufacturing companies using the AHP and TOPSIS approaches. // International Journal of Production Research. 43, 21(2005), pp. 4609-4641. DOl: 10.1080/00207540500161746

[20] Bang, W.; Chang, B. Y. Quality factor analysis of metal working process with AHP. // International Journal of Production Research. 51, 19(2013), pp. 5741-5756. DOI: 10.1080/00207543.2013.793422

[21] Patel, N.; Patel, R. K.; Patel, U. J.; Patel, B. P. Insert Selection for Turning Operation on CNC Turning Centre using MADM Methods. // International Journal of Latest Trends in Engineering and Technology. 1, 3(2012), pp. 4959.

[22] Sarfaraz, A.; Jenab, K.; D’Souza, A. C. Evaluating ERP implementation choices on the basis of customization using fuzzy AHP. // International Journal of Production Research. 50, 23(2012), pp. 7057-7067. DOl: 10.1080/00207543.2012.654409

[23] Triantaphyllou, E.; Mann, S. H. Using the analytic hierarchy process for decision making in engineering applications: some challenges. // International Journal of Industrial Engineering: Applications and Practice. 2, 1(1995), pp. 35-44.

\section{Authors' addresses}

Balasubramaniyan Singaravel, Research Scholar

Corresponding author

Production Engineering Department

National Institute of Technology

Tiruchirappalli, Tamilnadu, 620015 India

Email: vel_singara@yahoo.co.in

Dr. Thangiah Selvaraj, Professor,

Production Engineering Department

National Institute of Technology

Tiruchirappalli, Tamilnadu, 620015 India

Email: tselva@nitt.edu 